\title{
MIR26A2 Pre-miRNA
}

National Cancer Institute

\section{Source}

National Cancer Institute. MIR26A2 Pre-miRNA. NCI Thesaurus. Code C82721.

MIR26A2 pre-miRNA is an olig oribonucleotide that is encoded by the human MIR26A2 gene and is involved in the regulation of gene expression. 